覧床 Congenital dyserythropoietic anemia

\author{
type I の 1 症例
}

\begin{tabular}{|c|c|c|c|c|c|c|c|}
\hline \multicolumn{8}{|c|}{ 大阪大学医学部第二内科 } \\
\hline 平岡 & 諦॰ & 近江 & 伸和 & 首藤 & 弘史 & 谷口 & 信博 \\
\hline 金山 & 良男 & 河野 & 典夫 & 倉田 & 義之 & 米沢 & 毅 \\
\hline 木谷 & 照夫 & 垂井 & 一郎 & & & & \\
\hline
\end{tabular}

\title{
REPORT OF A CASE WITH CONGENITAL DYSERYTHROPOIETIC ANEMIA TYPE I
}

Akira Hiraoka, MD, Nobukazu Ohmi, MD, Hiroshi Sudo, MD, Nobuhiro Taniguchi, MD, Yoshio Kanayama, MD, Norio Kohno, MD, Yoshiyuki Kurata, MD,

Takeshi YoneZawa, MD, Teruo KITANI, MD and Seiichiro TARUI, MD, The Second Department of Internal Medicine, Osaka University Medical School

\begin{abstract}
拄要 無効造血と赤芽球形態異常を特徽とする先天性省血はcongenital dyserythropoietic anemia (CDA) と呼ばれ，形態的特徵より通常type I，II，飞区別されているが，世界的にも極めてをれ な疾患である.CDA type Iの1例を経験したので報告する.症例は27才，姓で薬斎師.両親は 6 親等にあたる血族結婚であるが，他に家族歷に異常を認めない，たまた急性肝炎を発症し当科に入 院した．肝资治瘾後も貧血（赤血球 246 万 $/ \mathrm{cmm})$ ，軽度の間揬ビリルビン高值 $(2.7 \mathrm{mg} / \mathrm{dl})$ が続いた. 肝炎治瘾後の現症では肝 1 横指，脾わずかに触知，両第 4 趾短趾症の他著変なし. 末梢血液像では奇 型赤血球，大小不同が顕著で網状赤血球の軽度増加をみたが，白血球，血小板には異常なかつた。骨 䯣では著明な赤芽球過形成がみられ，CDA type I 亿特徵的なinternuclear chromatin bridgeを赤芽球 の2.5\%隐めた。電顕にても赤芽球核の “spongy appearance” 等の特徽的形態を示した。赤血球寿 命の短縮愔軽度で，鉄動熊で㵔著明な無効造血を示した．Ham test陰性，赤血球解結系醉素，一モ グロビンに異常はみられなからた。本症の遺伝形式は常染色体劣性とされているが，本例もこれに矛 盾しない，本例で短趾症がみられたが，倹索し得たCDA type I，27例中 4 例に合指症，1 例に短指 症がみられ，Fanconi瑻血やDiamond Blackfan症候群と同様に，この様な骨格異常の合併は本症の特 徵の一つと考えられる。
\end{abstract}

\section{I. 緒 言}

1968年HeimpelとWendt ${ }^{1)}$ とつて 無効造血と 赤芽球形態異常を示す先天性貧血に対 L, congenital dyserythropoietic anemia (以下CDA と略) の名称が与えられ，赤芽球形態異常の特徵により 通常type I, II， IIIの3 型に分類されている. type IIは末梢赤血球膜にも異常がみられ，別名

[昭和54年 9 月 1 日 第99回近畿地方会推薦]
HEMPAS (hereditary erythroblastic multinuclearity with positive acid-serum test) とも呼ばれ ている ${ }^{2)}$. その他にtype I， II， III合致しない CDAの数例が報告されているが3) 一5)，いずれもそ の病因については不明である。これらCDAは世界 的にも極めてまれで, 最も多いtype II で80数例, type I， II では20数例の報告があるにすぎない． 著者らは最近CDA type Iの1例を経験したので 若干の文献的考察を加えて報告する. 


\section{I. 症例}

患者：27才，女，薬剤師。

主訴：黄疸，貧血

家族歴： 特記すべきものなしただし両親は 6 親等にあたる血族結婚である.

既往歴： 特記すべきものなし.

現病歴：生来体格小で顔色不良. 運動能では 特に長距離走を苦手とした. 22才時某院にて黄 疸, 貧血の精查を受け, primary shunt hyperbilirubinemiaの診断を受けた。昭和54年 4 月感冒様症 状に続き，食欲不振，全身倦意，黄疸增強 し， 4月24日に当科に入院した. 肝機能検査でGOT, GPT, alk-P-ase, $\gamma$-GTP, 黄疸指数の高值がみら れ，急性肝炎と診断した．約 2 力月の経過で肝炎 は治癒したが，肝炎治癒後も間接ビリルビンの高 值が続き，また入院時みられた貧血，末梢赤血球 の形態異常も引き続きみられprimary shunt hyperbilirubinemiaの診断に疑いを持ち，以下の検索を 行なつた。以下に述べる所見はいずれも肝炎治癒 後のものである.

現症： 身長 $151 \mathrm{~cm}$, 体重 $46 \mathrm{~kg}$. 脈拍 $87 /$ 分, 整. 血圧 $114 / 78 \mathrm{~mm} \mathrm{Hg}$. 眼球結膜軽度黄疸を認め, 䀫結膜貧血様. 頝部リンパ節触れず。 甲状腺腫 I . 胸部異常なし. 腹部では肝 1 横指触知し弾 性硬，表面平滑で圧痛なし，脾を肋弓下にわずか に触知する．腎触孔ず．神経学的異常所見なし．

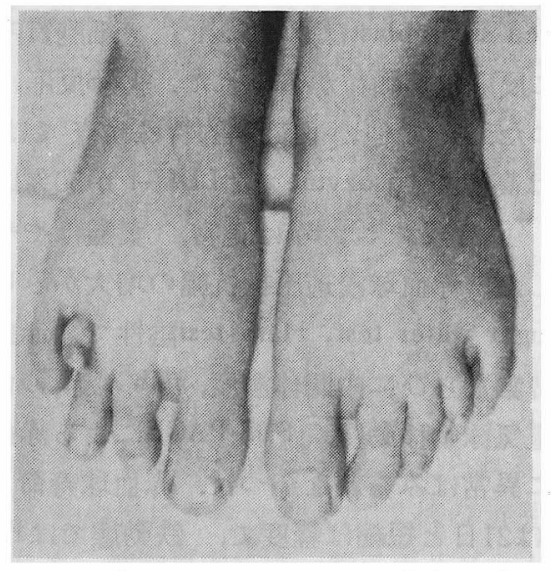

写真 1 . 両足第 4 趾の短趾症
表 1 . 一般検査成績

$\begin{array}{ll}\begin{array}{l}\text { Urinalysis } \\ \text { prot }\end{array} & (-) \\ \text { sugar } & (-) \\ \text { urob } & (+) \\ \text { bil } & (-)\end{array}$

ESR $18 \mathrm{~mm}\left(1^{\circ}\right)$

Serum chemistry

$\mathrm{Na} \quad 140 \mathrm{mEq} / \mathrm{l}$

$\mathrm{K} \quad 4.4$

Cl $\quad 103$

$\mathrm{Ca} \quad 4.4$

Pi $\quad 4.6 \mathrm{mg} / \mathrm{dl}$

BUN $\quad 10.1$

Uric Acid $\quad \mathbf{5 . 4}$

Creatinine 0.5

FBS $\quad 108$

Cholesterol 74

Triglyceride 106

B-lipoprotein 145

$\mathrm{Fe} \quad 189 \mu \mathrm{g} / \mathrm{d}$

UIBC 81

Liver function test

T.P $\quad 6.5 \mathrm{~g} / \mathrm{dl}$

Alb. $\quad 68.2 \%$

$\alpha:$ gl. $\quad 3.8$

$\alpha_{2} \quad 6.3$

$\begin{array}{ll}\beta & 4.4\end{array}$

$\gamma \quad 17.2$

\begin{tabular}{|c|c|c|}
\hline \multicolumn{2}{|c|}{ GOT } & $30 \mathrm{U}$. \\
\hline \multicolumn{2}{|c|}{ GPT } & 20 \\
\hline \multicolumn{2}{|c|}{ Al. Pase } & 6.2 \\
\hline \multicolumn{2}{|c|}{$\gamma$-GTP } & 16 \\
\hline \multicolumn{2}{|c|}{ ICG } & $4 \%\left(15^{\prime}\right)$ \\
\hline \multicolumn{2}{|c|}{ CoR } & Rs \\
\hline \multicolumn{3}{|c|}{ Bilirubin } \\
\hline \multicolumn{2}{|c|}{ total } & $3.3 \mathrm{mg} / \mathrm{dl}$ \\
\hline \multicolumn{2}{|c|}{ direct } & 0.6 \\
\hline \multicolumn{2}{|c|}{ indirect } & 2.7 \\
\hline \multicolumn{3}{|c|}{ Serological test } \\
\hline \multicolumn{3}{|c|}{ CRP $\quad(-)$} \\
\hline \multicolumn{3}{|c|}{ RA $\quad(-)$} \\
\hline \multicolumn{2}{|c|}{ HBs Ag (-) } & $\mathrm{HBe}(-)$ \\
\hline \multicolumn{2}{|c|}{$A b(-)$} & $\mathrm{HBC}(-)$ \\
\hline \multicolumn{2}{|c|}{ Coombs test } & direct $(-)$ \\
\hline \multicolumn{3}{|c|}{ PPD $\quad(+)$} \\
\hline \multicolumn{3}{|c|}{ Serum Ig } \\
\hline \multicolumn{3}{|c|}{$\operatorname{lgG} \quad 1282 \mathrm{mg} / \mathrm{dl}$} \\
\hline \multicolumn{3}{|c|}{$\operatorname{Ig} A \quad 233$} \\
\hline \multicolumn{3}{|c|}{$\lg M \quad 211$} \\
\hline \multicolumn{2}{|c|}{ Thyroid test } & $(-)$ \\
\hline \multicolumn{3}{|c|}{ Microsome test } \\
\hline \multicolumn{3}{|c|}{ hyroid function } \\
\hline$T_{3}$ & $148 \mu \mathrm{g} /$ & \\
\hline$T_{4}$ & 8.2 & \\
\hline TSH & $6.9 \mu \mathrm{U}$ & \\
\hline
\end{tabular}

両足第 4 趾に短趾症を認める（写真 1 ).

検査所見：一般検査（表 1) では尿ウロビリ ノーゲンの増加, 血沈軽度方進を示す. 血液化学 的検査では電解質，尿素窒素，尿酸等に異常な し. コレステロールは $74 \mathrm{mg} / \mathrm{dl}$ と著明な 低值を示 し， $\beta$-lipoproteinの低値がみられた。血清鉄値の 上昇，UIBCの低下をみる，肝機能検査では膠質 反応に軽度の 異常をみる他はGOT, GPT, alk-Pase， $\gamma$-GTP，ICG排泄も正常であつたが，間接ビ リルビン值は $2.7 \mathrm{mg} / \mathrm{dl}$ と高值が 続いている. 胸部 $\mathrm{X}$ 線像, 心電図に異常なく, 内分泌学的, 血清学 的検査にも著変を認めない.

血液学的検查 (表 2 ) では赤血球数 $246 \times 10^{4} / \mathrm{cmm}$ 血色素 $8.1 \mathrm{~g} / \mathrm{dl}, \mathrm{Ht} 25.1 \%$ とやや大球性の正色 素性貧血があり，赤血球形態は大小不同，奇型 赤血球が顕著で, anisochromia，塩基性斑点も認 められた（写真 2 ). 網状赤血球は 17〜 53\% と軽 度の増加がみられた。白血球数，およびその分 類, 血小板数は正常であつた. 他の止血検查にも 
表 2 . 血液学的検査成績

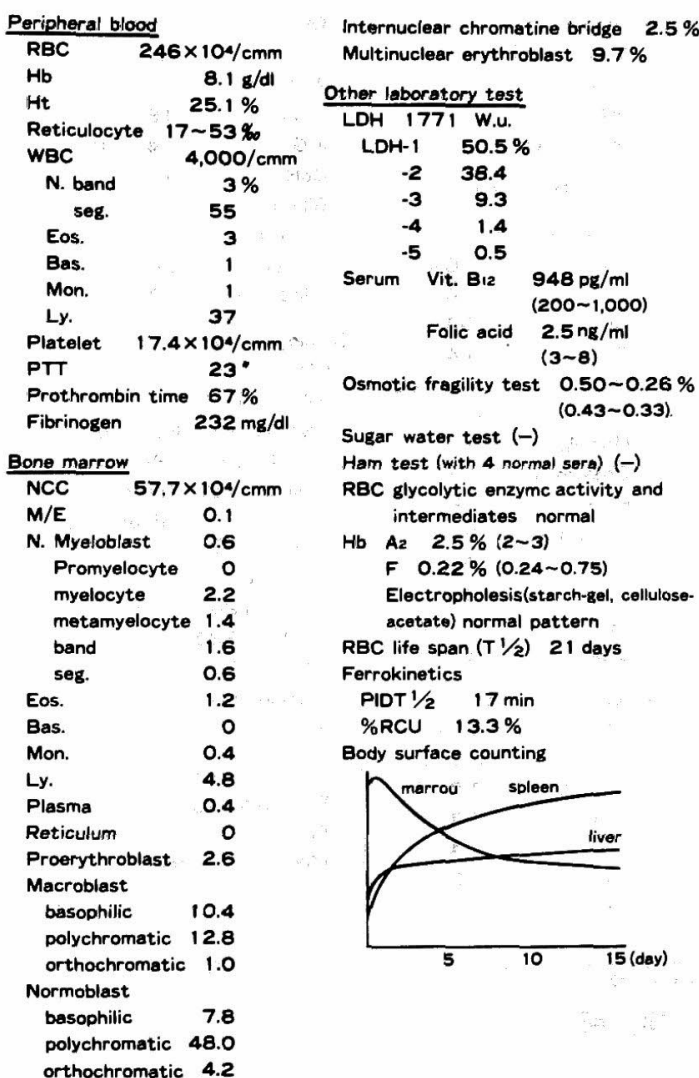

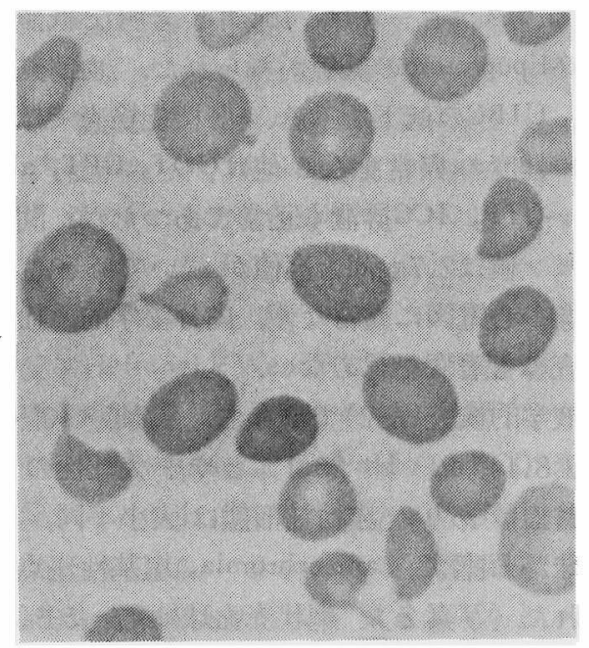

写真 2 . 末梢血塗抹標本：大小不同, 奇型赤血球 が顕著でanisochromia, 塩基性斑点も認める。

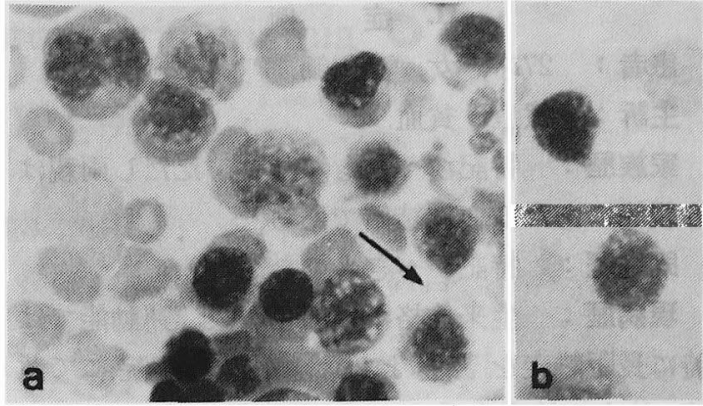

写真 3.骨髄塗抹標本：a）ギムザ染色, 赤芽球過形 成,巨赤芽球様の変化の他, internuclear chromatin bridge (矢印), 二核やダルマ型の核を有する赤芽 球を認める。 b) Feulgen反応，internuclear chromatin bridgeが本反応陽性であることを示す.

著変を認めない，骨髄像 では有核細胞数 $57.7 \times$ $10^{4} / \mathrm{cmm}, \mathrm{M} / \mathrm{E}$ 比 0.1 と著明なerythroid hyperplasia がみられ，赤芽球核クロマチンの凝集は巨赤芽球 様の変化を示したが，悪性貧血等にみられる巨赤 芽球よりは個々のクロマチン凝集は粗大で不分明 である。赤芽球の $9.7 \%$ に多核（主に2核）赤芽 球を認め，また核分離異常と思われるダルマ型あ るいはピーナッツ型をした核も散見される。CDA type I 飞特街的なinternuclear chromatin bridge を2.5\%に認めた（写真 3a). これにFeulgen反応 を行ならとchromatin bridgeが 本反応陽性である ことがわかる(写真 3b). 鉄染色ではsideroblast を28\%に認めたが, sideroblastic anemiaにみられ るringed sideroblastは認められず，細胞質内に散 在性に反応陽性顆粒がみられた。PA反応は陰性 であつた：その他の 血液学的特殊検查では血清 LDHは高值で，isozymeではLDH-1 が50\%以上を 占め, 血清ビタミン $\mathrm{B}_{12}$ は正常, 葉酸はやや低值 を示した. 赤血球浸透圧抵抗幅の増大がみられた が, sugar water test, Ham test陰性で, 赤血球解

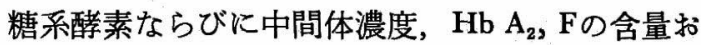
よび電気泳動移動度, SDS-PAGEによる赤血球膜 蛋白に異常はみられなかつた。赤血球寿命 $\left({ }^{51} \mathrm{Cr}\right)$ $\mathrm{T} 1 / 2$ 21日と短縮は軽度で, 鉄動態ではPID T 1/2，17分，\%RCU $13.3 \%$ と著明な無効造血を示 

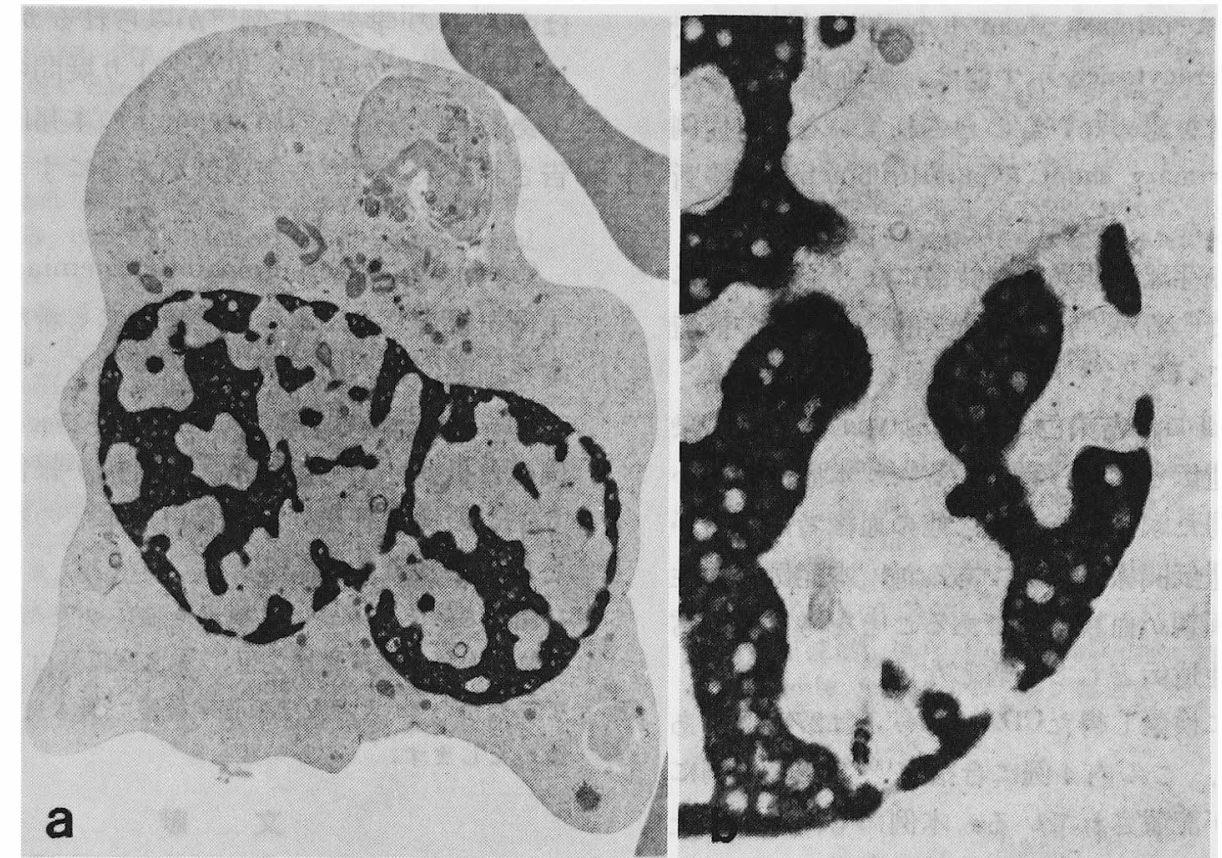

写真 4. 赤芽球電顕像： a) 核は特徵的な “spongy appearance”を示し，核内に細胞質内小器官を 認める. 時にこの様なダルマ型や 2 核もみられる. 細胞質にはポリッームが少なく, autophagosome やミエリン構造を認める，b）著明な核膜の陥入を示す。

し，体表計測でも無効造血のパターンを示した.

赤弟球電顕形態（写真 4）：これまでの報告 にみられると同様に，前赤芽球など幼若赤芽球に は著変なく, 形態異常は主として多染赤芽球以後 の成熟赤芽球にみられた。最も特徵的なことは核 異常で，巨赤芽球にみられる核構造とは全く異な ク，クロマチンは地図状に著明に凝集し，一テロ クロマチンとその他の部分が明瞭に分かれた形を とる. その凝集部内が斑紋状に抜け，また核内に しばしば細胞質内小器官を認める。これは写真 $4 \mathrm{~b}$ に示す様に，核膜の著明な陥入によると考えられ る.これまでの文献では,核膜孔の異常開大による 細胞質の核内侵入が考えられているが，透過型電 顕のみではこれを明確にはとらえがたく，freezeetching法等による検索が 必要と考えられる。時 には写真 $4 \mathrm{a}$ の様にダルマ型や， 2 核の 赤芽球も 認められる，細胞質内には一般にポリゾームが少 なく，しばしばautophagosomeやミエリン構造を
みる、微小管やミトュンドリア内鉄顆粒むしばし ばみられる。

以上著明な無効造血と特有の赤芽球形態異常よ り, 本症例をCDA type I と診断した.

家系調查：両親は 6 親等の関係にあたる血族 結婚である，両親，兄妹，および他の 3 名の血 縁者について検血および血清脂質検査を行なつた か゚，貧血，赤血球形態異常，低コレステロール血 症を示すものはみられなかつた。

\section{II. 考 案}

本例は急性肝炎でたまたま入院したが，肝炎治 癒後も, 黄疸, 貧血, 赤血球形態異常がみられ, その後の検索によりCDA type I と診断された症 例である。

1959年Israelsらは，無効造血によつて生じる高 ビリルビン血症をshunt hyperbiliruebinemia と呼 び，サラセミアや悪性貧血など起因疾患の明らか なものをsecondary，原因不明のものをprimaryと 
区別した ${ }^{6)}$. primary shunt hyperbilirubinemiaで は時にspherocytosis示す他は，赤血球，赤芽球 に形態異常を認めないものとされている，本症例

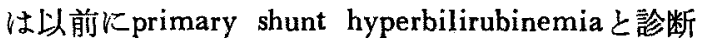
されているが，これには当らない．

CDAは赤芽球形態異常の特徽により通常 3 型に 区別されているが，電顕形態学的にも特有の構造 が示されている7゙． CDA 3 型の遺层形式は, type I, II では常染色体劣性, type II では常染 色体優性遺伝と考兄られている3 。 本症例につい ては調べ得た家系調查では，他の血縁者に異常が みられす遺伀関係は不明であるが，本症例が女性 であり，両親が血族結婚であることを考点ると常 染色体劣性遗伝として矛盾しない.

文献的に検索し得たCDA type Iは27症例であ

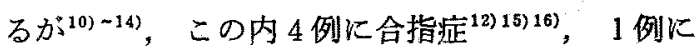

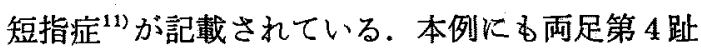
に短趾症がみられ，この様な骨格異常は，やはり 先天性の貧血症であるFanconi貧血や，Diamond Blackfan症候群と同様に, CDA type I の特徽の 一つと考劣られる。

本症では血清コレステロールの著明な低值がみ られたが，これは急性肝炎発症前にも確かめられ ている，一般に貧血に伴つて，貧血の原因に関係 なく血清コレステロール值は低值を示し，貧血の 回復につれ正常化するとされているが，その原因 については汪とんど分かつていない" ${ }^{17)}$. CDA type I，27例中血清コレステロール值の記載のある 5

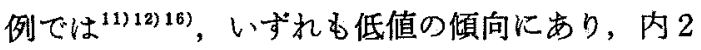
例では本例と同様に著明な低值を示している。こ のコレステロール低値は，上記の様な一般的な筫 血に伴う現象なのか, CDA type I の病因と関連 した成績なのか不明である，本例の両親，兄姝に

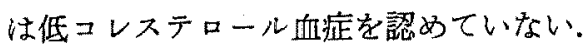

本邦に抢けるCDAの報告例をみると，小圾らの 報告例 ${ }^{18)}$, 抒よび大景らの学会報告例 ${ }^{199}$ は, 赤血球 膜異常や電顕形態学的検索はなされていないが， 光顕形態抽よび遺伝形式よりCDA type II 属す るものと考えられる。一方CDA type IKついて

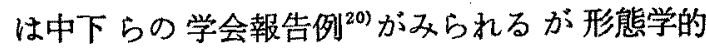
に，また葉酸の治療効果などより疑問のある症例 である.典型的なCDA type Iの本邦例は最近報 告された栗林ら ${ }^{14)}$ の姉弟例があるにすぎない。

\section{IV. 結 語}

Congenital dyserythropoietic anemia type Iの 1 例を報告した，本症は世界的にも希な疾患で， 本邦姉弟例を含め27例の報告をみるにすぎない， 本例江両足第 4 趾の 短趾症をみたが，27例中 4 例に合指症，1例飞短指症の合併が報告されてお ク,この様な骨格異常の合併は本症の特改の一つ と考えられる。

謝辟 へモグロビンの検索をしていただいた大阪大 学第三内科：藤田富雄先生，赤血球膜蛋白の検索をし ていたたいた大服大学栄養学教室 河本良平先生に知 謝いたします。

\section{文献}

1) Heimpel $\mathrm{H}$ and Wendt $\mathrm{F}$ : Congenital dyserythropoietic anemia karyorrhexis and multinuclearlity of erythroblasts. Helv Med Acta 34: 103, 1968.

2) Crookston JH, et al: Hereditary erythroblastic multinuclearity associated with a positive acidified-serum test: a type of congenital dyserythropoietic anemia. Brit J Haemat 17: 11, 1969.

3) Miller DR: Erythropoiesis and hypoplastic anemia. Miller DR, et al, ed. Smith's Blood Diseases of Infancy and Childhood, Mosby, StLouis, 1978, p 212.

4) Benjamin JT, et al: Congenital dyserythropoietic anemia-type IV. J Pediat 87: 210, 1975.

5) Weatherly $T L$, et al: Congenital dysery thropoietic anemia (CDA) with increased red cell lipids. Amer J Med 57: 912, 1974.

6) Israels LG and Zipursky A: Primary shunt hyperbilirubinemia. Nature (Lond) 193: 73, 1962.

7) Heimpel H, et al: Electron and light microscopic study of the erythroblasts of patients with congenital dyserythropoietic anemia. Blood 37: 299, 1971.

8) Lewis SM, et al: Clinical and ultrastructural aspects of congenital dyserythropoietic anemia type I. Brit J Haemat 23: 113, 1972. 
9) Breton-Gorius PJ, et al: Anomalies ultrastructurales des érythroblastes et des érythrocytes dans six cas de dysérythropoiese congénitale. Nouv Rev Fr d'Hémat 13: 23, 1973.

10) Heimpel H: Congenital dyserythropoietic anemia type I: clinical and experimental aspects. CIBA Foundation Symposium 37 Congenital Disorders of Erythropoiesis, Elsevier/Excerpta Medica/North - Holland, Amsterdam, Oxford, New York, 1976, p135.

11) Holmberg L, et al: Type I congenital dyserythropoietic anemia with myelopoietic abnormalities and hand malformations. Scand J Haematol $21: 72,1978$.

12) Jean $R$, et al: Anemie dyserythropoietique congenitale, type I. Arch Franç Péd 32: 337, 1975.

13) Lay HN, et al: Congenital dyserythropoietic anemia type $I$ in two brothers presenting with neonatal jaundice. Arch Dis Child 53: $753,1978$.

14) Kuribayashi $T$, et al: Congenital dyserythropoietic anemia type 1 : report of a pair of siblings in Japan. Blut 39: 201, 1979.

15) Heimpel $\mathrm{H}$, et al: Kongenitale dyserythropoietische anämie. Arch Klin Med 215: 174, 1968.

16) Clauvel JP, et al: Dysérythropoiese congénitale (étude de 6 observations). Nouv Rev Fr Hématol 12: 653, 1972.

17) Westerman MP, et al: Hypocholesterolemia and anemia. Brit J Haemat 31: 87, 1975.

18）小圾 晋，他：家族性赤芽球核異常。日血会誌 $21: 80,1958$.

19) 大裝 収, 他: 赤芽球核異常定の一例.日血会 䓌（会） $33: 123,1970$.

20) 中下誠郎, 他 : Congenital dyserythropoietic anemia と思晾机る1例. 臨床血液（会）16： $88,1975$. 